\title{
Rapeseed Oil Monoester of Ethylene Glycol Monomethyl Ether as a New Biodiesel
}

\author{
Jiang Dayong, Wang Xuanjun, Liu Shuguang, and Guo Hejun \\ Xi'an Research Institute of High Technology, Xi'an, Shaanxi 710025, China \\ Correspondence should be addressed to Jiang Dayong, wanghe717@163.com \\ Received 19 July 2010; Revised 8 December 2010; Accepted 3 January 2011 \\ Academic Editor: R. S. Tjeerdema \\ Copyright () 2011 Jiang Dayong et al. This is an open access article distributed under the Creative Commons Attribution License, \\ which permits unrestricted use, distribution, and reproduction in any medium, provided the original work is properly cited.
}

\begin{abstract}
A novel biodiesel named rapeseed oil monoester of ethylene glycol monomethyl ether is developed. This fuel has one more ester group than the traditional biodiesel. The fuel was synthesized and structurally identified through FT-IR and $\mathrm{P}^{\mathrm{IP}} \mathrm{H}$ NMR analyses. Engine test results show that when a tested diesel engine is fueled with this biodiesel in place of 0\# diesel fuel, engine-out smoke emissions can be decreased by $25.0 \%-75.0 \%$, CO emissions can be reduced by $50.0 \%$, and unburned HC emissions are lessened significantly. However, NOx emissions generally do not change noticeably. In the area of combustion performance, both engine in-cylinder pressure and its changing rate with crankshaft angle are increased to some extent. Rapeseed oil monoester of ethylene glycol monomethyl ether has a much higher cetane number and shorter ignition delay, leading to autoignition $1.1^{\circ} \mathrm{CA}$ earlier than diesel fuel during engine operation. Because of certain amount of oxygen contained in the new biodiesel, the engine thermal efficiency is improved $13.5 \%-20.4 \%$ when fueled with the biodiesel compared with diesel fuel.
\end{abstract}

\section{Introduction}

In recent years, growing awareness of the complete depletion of petroleum oil in the near future and serious atmospheric pollution caused by automobile industry has inspired much research for clean alternative fuels to substitute for fossil fuels $[1-3]$. One of the most promising alternative energy sources is biodiesel. Biodiesel contains significantly less sulfur and nitrogen, which makes the fuel more environment-friendly than petroleum fuels. Because it is renewable and available worldwide, it has a bright future for practical application. A traditional biodiesel used to be the methyl ester of vegetable oil, which is prepared through transesterification of vegetable oils such as rapeseed oil, peanut oil, and soybean oil with methanol. Many studies have revealed that such biodiesel, containing a certain amount of oxygen, can lead to remarkable reduction in diesel engine exhaust emissions [4-6]. Thus, it has been called a green fuel for diesel engine. However, because it has only one ester group (i.e., two oxygen atoms, existing in each monoester molecule), the oxygen content in conventional biodiesel is comparatively low. Consequently, the reduction in smoke emissions is not as significant as anticipated used in diesel engines when mixed with diesel fuel. Experiments have shown that the reduction rate in engine-out smoke emissions is correlated with the oxygen content of the fuel. To enhance the effect of traditional biodiesel in reducing engine-out smoke formation, the introduction of other ether group into its molecule has been attempted. Rapes are largely planted in China, and rapeseed oil is a vegetable oil extensively used for food. Therefore, a new type of biodiesel, rapeseed oil monoester of ethylene glycol monomethyl ether, is synthesized in this paper. This study focuses on its performance in reducing engine-out exhaust emissions and combustion.

\section{Experimental Section}

2.1. Preparation and Structure Analysis. The new rapeseed oil monoester was synthesized using a commercial refined rapeseed oil and ethylene glycol monomethyl ether as reactants. Initially, the selected rapeseed oil was treated through extraction with ethanol as solvent at a temperature of $90^{\circ} \mathrm{C}$ to remove tiny amounts of organic fatty acid. It was then purified under vacuum condition. FT-IR analysis verified that there was no vibration $(-\mathrm{OH})$ absorption peak in the 


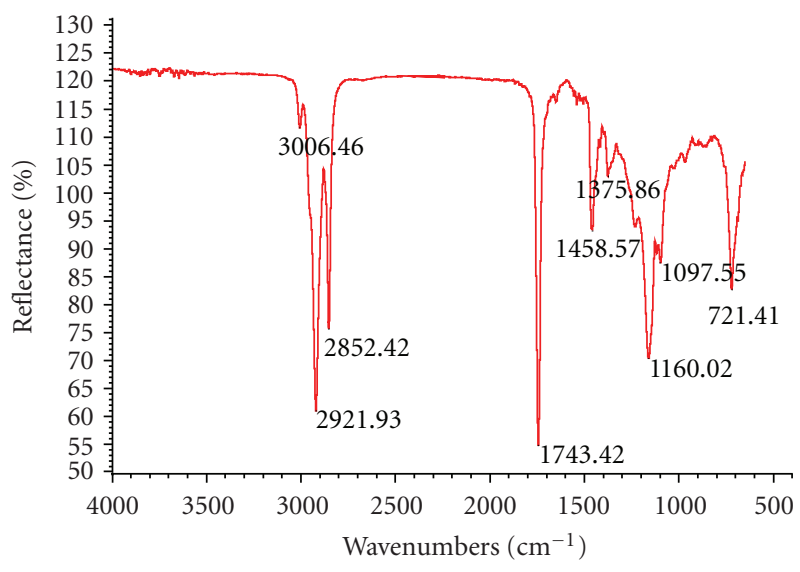

FIGURE 1: IR spectrum of rapeseed oil after pretreatment.

TABLE 1: Specification of the used chemicals.

\begin{tabular}{|c|c|c|c|c|}
\hline Chemicals & $\begin{array}{r}\text { Density/ } \\
\mathrm{kg} \cdot \mathrm{m}^{-3}\end{array}$ & $\begin{array}{c}\text { Boiling } \\
\text { point } /{ }^{\circ} \mathrm{C}\end{array}$ & $\begin{array}{c}\text { Molecular } \\
\text { weight }\end{array}$ & Standard \\
\hline Rapeseed oil & 909-914 & - & - & primes state \\
\hline $\begin{array}{l}\text { Ethylene } \\
\text { glycol } \\
\text { Monomethyl } \\
\text { ether }\end{array}$ & 965.0 & 134 & 76.10 & $\begin{array}{l}\text { analytically } \\
\text { pure }\end{array}$ \\
\hline $\begin{array}{l}\text { Ethanol } \\
\text { absolute }\end{array}$ & 789-791 & 78 & 46.07 & $\begin{array}{l}\text { analytically } \\
\text { pure }\end{array}$ \\
\hline Potassa & 950 & - & 23.5 & $\begin{array}{l}\text { chemically } \\
\text { pure }\end{array}$ \\
\hline
\end{tabular}

region of $3200-3600 \mathrm{~cm}^{-1}$, indicating that there was little fatty acid and ethanol in the treated rapeseed oil (Figure 1, Table 1).

The subsequent transesterification reaction was carried out in a flask with the acid-free rapeseed oil of $600 \mathrm{~mL}$ and ethylene glycol monomethyl ether of $210 \mathrm{~mL}$ at a temperature of $65^{\circ} \mathrm{C}$ using $0.6 \% \mathrm{KOH}$ as catalys,. Upon completion of the reaction which lasted for approximately $2 \mathrm{~h}$, the crude product was first neutralized with diluted $\mathrm{HCl}$ solution and separated from the water phase. Subsequently, it was purified in a vacuum to remove ethylene glycol monomethyl ether left over in the ester phase. Finally, it was dried using $\mathrm{CaCl}_{2}$ agent [7].

Gel permeation chromatography (GPC) can help simultaneously detect diglyceride, triglyceride, glycerol, and fatty acid content of methyl ester in the process of transesterification reaction with a refractive index detector. The main component of rapeseed oil is fatty acid glycerin ester, whose number average molecular weight is approximately 1426 or so. This is consistent with the known composition of rapeseed oil. After transesterification, the peak of fatty acid ester (Mw 1426) had almost disappeared, which means fatty acid glycerides have been transformed into fatty acid ether ester (biodiesel) thoroughly. Correspondingly, the peaks of number average molecular weight of 564 and 338 have appeared (Figure 2, Table 2).
TABLE 2: GPC Data of rapeseed oil monoester.

\begin{tabular}{lcccccc}
\hline Peak & & Mn & MP & RT/min & $\begin{array}{c}\text { Area/ } \\
\text { mVsecs }\end{array}$ & $\begin{array}{c}\text { Peak } \\
\text { area/\% }\end{array}$ \\
\hline \multirow{2}{*}{$\begin{array}{lccccc}\text { Rapeseed } \\
\text { oil }\end{array}$} & I & 2713 & 2649 & 23.363 & 4041 & 0.55 \\
& II & 1426 & 1382 & 24.921 & 696199 & 95.25 \\
& IV & 1005 & 1029 & 25.622 & 9767 & 1.34 \\
& V & 568 & 893 & 25.931 & 9626 & 1.32 \\
Rapeseed & I & 1105 & 1038 & 25.604 & 176060 & 16.29 \\
oil & II & 564 & 525 & 26.858 & 365764 & 33.83 \\
Monoester & III & 338 & 337 & 27.405 & 539238 & 49.88 \\
\hline
\end{tabular}

TABLE 3: Specification of DI diesel engine utilized.

\begin{tabular}{|c|c|c|c|}
\hline Parameter & Magnitude & Parameter & Magnitude \\
\hline Bore & $100 \mathrm{~mm}$ & Rated speed & $2300 \mathrm{rpm}$ \\
\hline Stroke & $115 \mathrm{~mm}$ & Rated power & $11 \mathrm{kw}$ \\
\hline $\begin{array}{l}\text { Connecting } \\
\text { rod length }\end{array}$ & $190 \mathrm{~cm}$ & $\begin{array}{c}\text { Combustion } \\
\text { chamber }\end{array}$ & $\omega$ shape \\
\hline Displacement & $0.903 \mathrm{~L}$ & $\begin{array}{l}\text { Compression } \\
\text { ratio }\end{array}$ & 18 \\
\hline
\end{tabular}

2.2. Engine Test. A single cylinder, four-stroke, water-cooled, DI diesel engine was adapted to complete the determination of exhaust emissions and combustion performances. The technical parameters of the engine are presented in Table 3. An AVL DiSmoke 4000 smoke opacity indicator was used to record smoke number in extinction coefficient, and an online exhaust emission analyzer was utilized to examine NOx, $\mathrm{CO}$, and $\mathrm{HC}$ emitted. An angle calibration apparatus and a kistler pressure transducer were used to pick up crankshaft angle and in-cylinder pressure. A CS20000 Data Gathering and Analyzing System was utilized to process data [8].

For comparison study, a 0\# diesel fuel meeting China national technical specification was utilized and named $\mathrm{B} 0$. B0 was mixed with the rapeseed oil (B100) monoester in a proportion of $1: 1$ by volume to investigate effect of the mixture (B50) on engine-out exhaust emissions and combustion performance [9-12].

The engine tests were carried out under the following conditions: ambient temperature of $23^{\circ} \mathrm{C}$, humidity of $71 \%$, and engine water-cooling temperature of $70^{\circ} \mathrm{C}$. In the experiment, when the engine achieved stable operation at a fixed steady state, of the necessary determinations were made according to certain well-defined procedures.

\section{Results and Discussion}

3.1. Chemical Structure. Figure 3 and Table 4 list the main absorption frequencies displayed in IR spectrum obtained for the new rapeseed oil monoester. No absorption peaks above $3100 \mathrm{~cm}^{-1}$ was found, implying that there is no hydroxyl group $(-\mathrm{OH})$ in the molecules of the synthesized product. So, it is easily confirmed that the product is an ester 


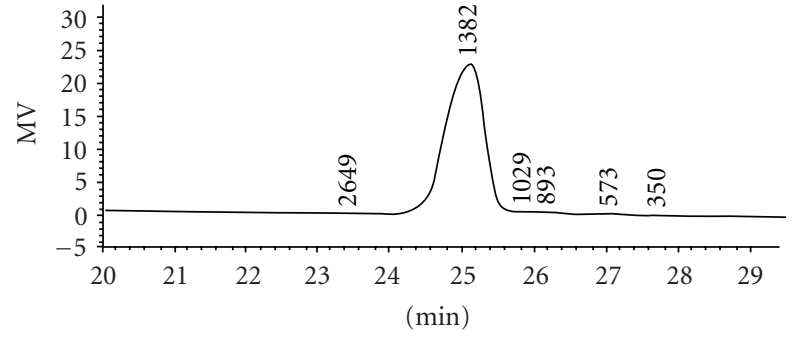

(a) rapeseed oil

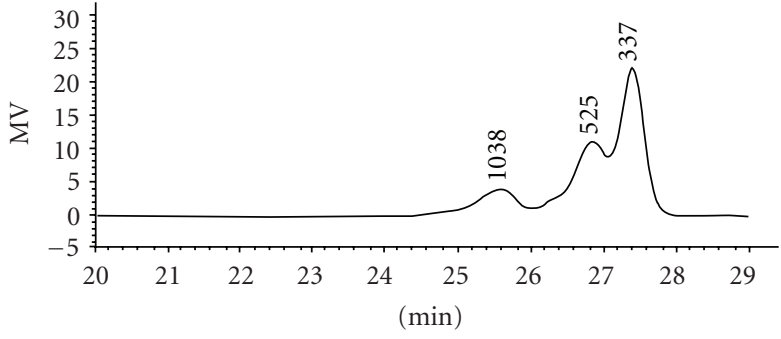

(b) rapeseed oil monoester

FIGURE 2: GPC spectrum of rapeseed oil and rapeseed oil monoester.

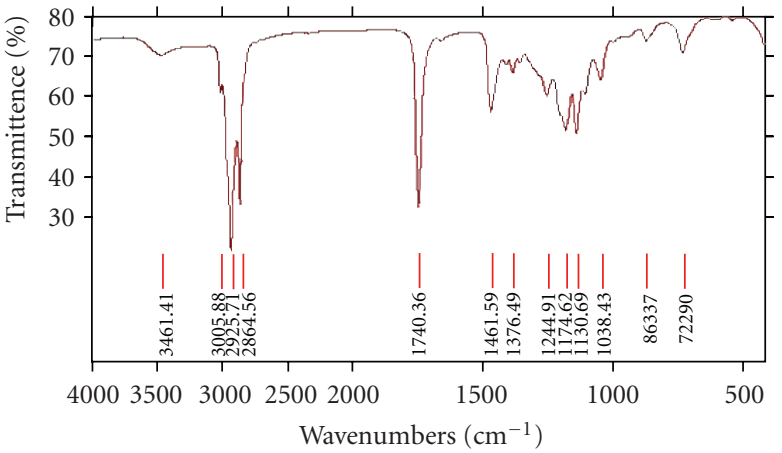

FIGURE 3: IR spectrum of rapeseed oil monoester.
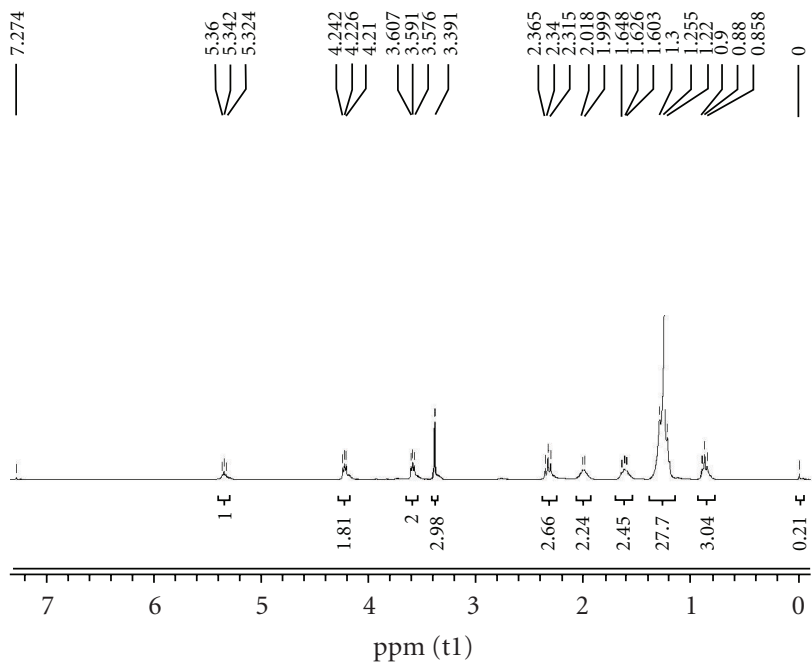

FIGURE 4: $\mathrm{P}^{1 \mathrm{P}} \mathrm{H}$ NMR spectrum of rapeseed oil monoester.

involving an ether group. Figure 4 and Table 5 illustrate its $\mathrm{P}^{1 P} \mathrm{H}$ NMR data collected. Chemical shift $5.359 \mathrm{ppm}$ belonged to the protons attaching to the $\mathrm{C}=\mathrm{C}$ group in the rapeseed oil monoester molecules, and chemical shift of $4.228,3.596$, and $3.395 \mathrm{ppm}$, respectively, belonged to the protons existing in the group $-\mathrm{COOCH}_{2} \mathrm{CH}_{2} \mathrm{OCH}_{3}$ in the order from left to right. The peaks occurring in the chemical shift region below $2.771 \mathrm{ppm}$ all were attributed to protons in the fatty groups $(-\mathrm{R})$ and other non-fatty ester compounds. Therefore, the chemical structure of the new
TABLE 4: Data of FT-IR spectrum of rapeseed oil monoester.

\begin{tabular}{lccc}
\hline Frequency/cm & Group attribution & Vibration type & Strength \\
\hline 2925.71 & $-\mathrm{CHB}_{3 \mathrm{~B}},-\mathrm{CHB}_{2 \mathrm{~B}}$ & $\nu \mathrm{B}_{\mathrm{asB}}$ & $\mathrm{s}$ \\
2854.56 & $-\mathrm{CHB}_{3 \mathrm{~B}},-\mathrm{CHB}_{2 \mathrm{~B}}$ & $\nu \mathrm{B}_{\mathrm{sB}}$ & $\mathrm{s}$ \\
1740.36 & $\mathrm{C}=\mathrm{O}$ & $\nu$ & $\mathrm{s}$ \\
1461.59 & $-\mathrm{CHB}_{2 \mathrm{~B}}$ & $\delta$ & $\mathrm{m}$ \\
1376.49 & $-\mathrm{CHB}_{3 \mathrm{~B}}$ & $\delta$ & $\mathrm{m}$ \\
1244.91 & $\mathrm{C}-\mathrm{O}-\mathrm{C}$ & $\nu \mathrm{B}_{\mathrm{asB}}$ & $\mathrm{m}$ \\
1174.62 & $\mathrm{C}-\mathrm{O}-\mathrm{C}$ & $\nu \mathrm{B}_{\mathrm{sB}}$ & $\mathrm{m}$ \\
722.90 & $\left(\mathrm{CH}_{2}\right) n(n>4)$ & - & $\mathrm{w}$ \\
\hline
\end{tabular}

prepared rapeseed oil monoester was easily confirmed as $\mathrm{RCOOCH}_{2} \mathrm{CH}_{2} \mathrm{OCH}_{3}$.

3.2. Exhaust Emissions. Two types of engine operation modes running at 1400 and $2000 \mathrm{rpm}$, respectively, were selected to study the exhaust emissions changes under different brake mean effective pressures (BMEP). Figure 5 displays the effects of the new rapeseed oil monoester on engineout smoke emissions at 1400 and $2000 \mathrm{rpm}$, respectively. Clearly, a considerable decrease in smoke emissions has been achieved in the experiment. When the engine burnt B100 under partial loads at $1400 \mathrm{rpm}$, there was a relative reduction in smoke emissions by $25.0 \%-56.5 \%$ within the tested partial load range compared with B0. A decrease of $25.9 \%-75.0 \%$ was also obtained for B50. At $2000 \mathrm{rpm}$, reductions of $43.5 \%-72.2 \%$ and of $25.0 \%-38.8 \%$ were reached, respectively, for $\mathrm{B} 100$ and $\mathrm{B} 50$ within the tested partial load range. As an oxygenated fuel containing more than $10 \%$ oxygen, the molecule of biodiesel does not contain aromatics. In addition, its hydrocarbon ratio $(\mathrm{C} / \mathrm{H})$ is far less than that of saturated hydrocarbons. Oxygen capacity can be improved through the issue of local hypoxia and smoke mainly generated in the diffusion combustion. Thus, the accession of biodiesel can increase premixed combustion, and decrease diffusion combustion, especially in areas of high fuel concentration, reducing the oxygen fuel combustion, and thereby reducing the soot emissions.

Figure 6 reveals that $\mathrm{CO}$ emissions reduced noticeably at the speed of 1400 and $2000 \mathrm{rpm}$. At $1400 \mathrm{rpm}, \mathrm{CO}$ emissions were lessened by $25.0 \%-33.3 \%$ when the tested engine burned B100; a slightly larger decline occurred for B50 


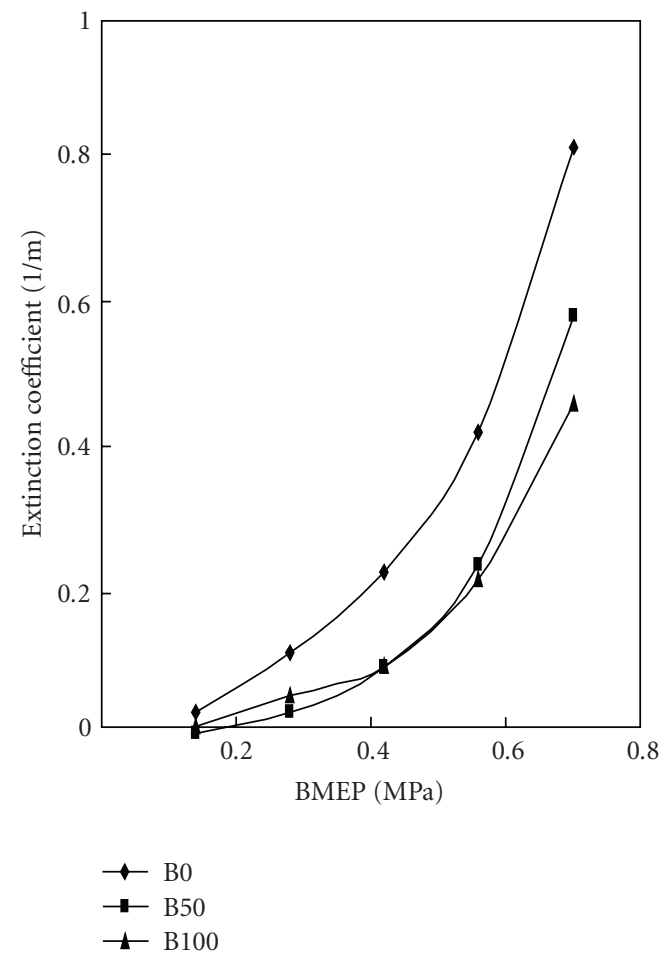

(a) $1400 \mathrm{rpm}$

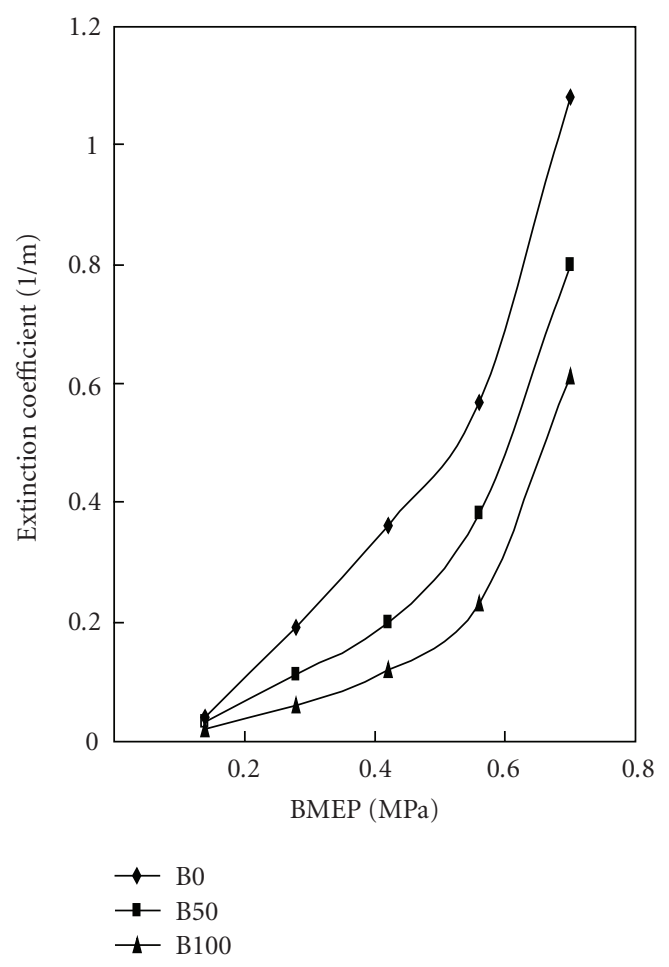

(b) $2000 \mathrm{rpm}$

Figure 5: Effect of the rapeseed oil monoester on smoke emissions.

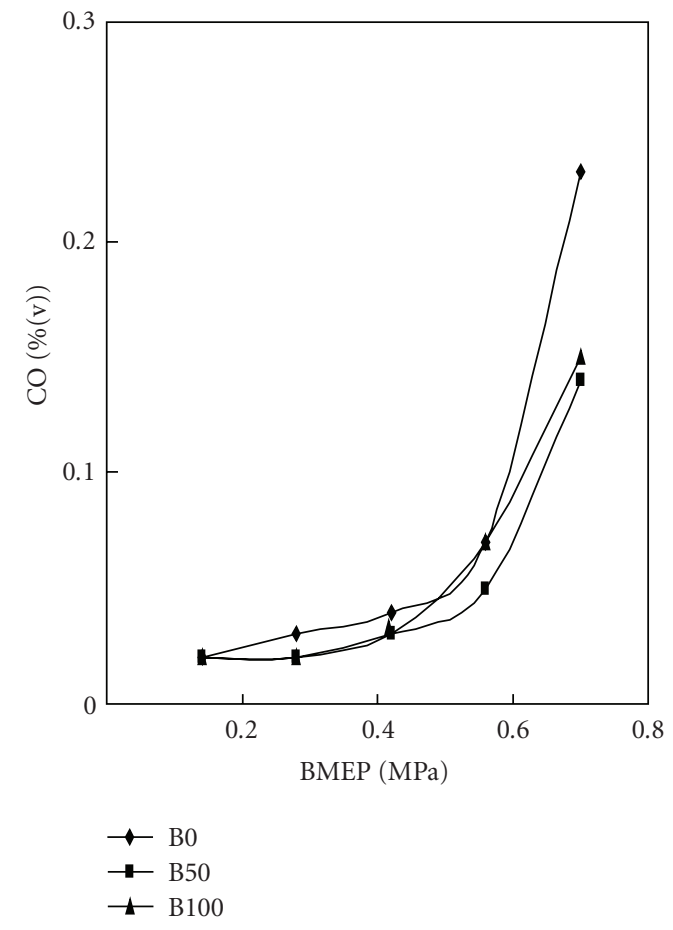

(a) $1400 \mathrm{rpm}$

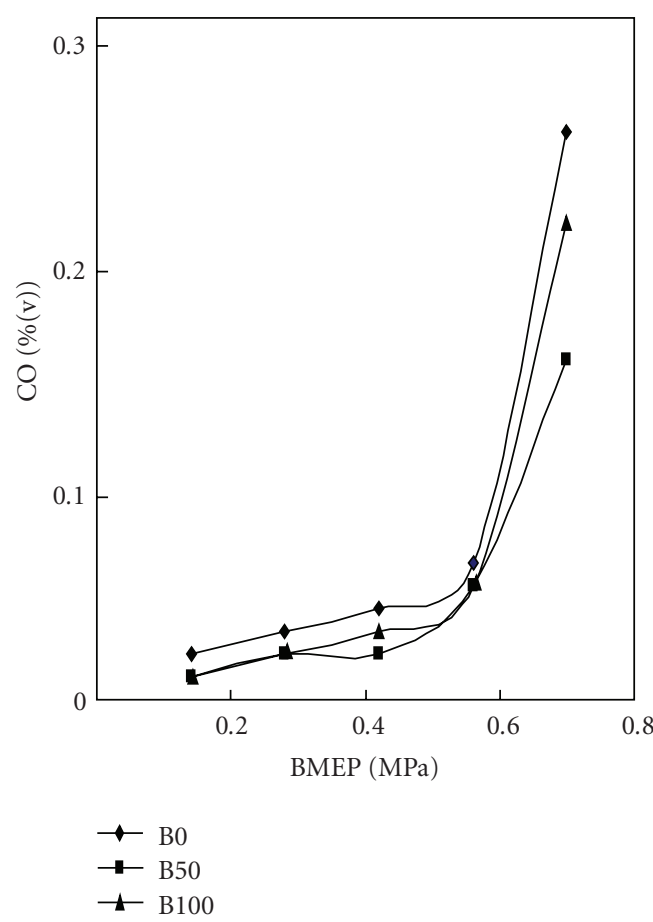

(b) $2000 \mathrm{rpm}$

Figure 6: Effect of the rapeseed oil monoester on CO emissions. 


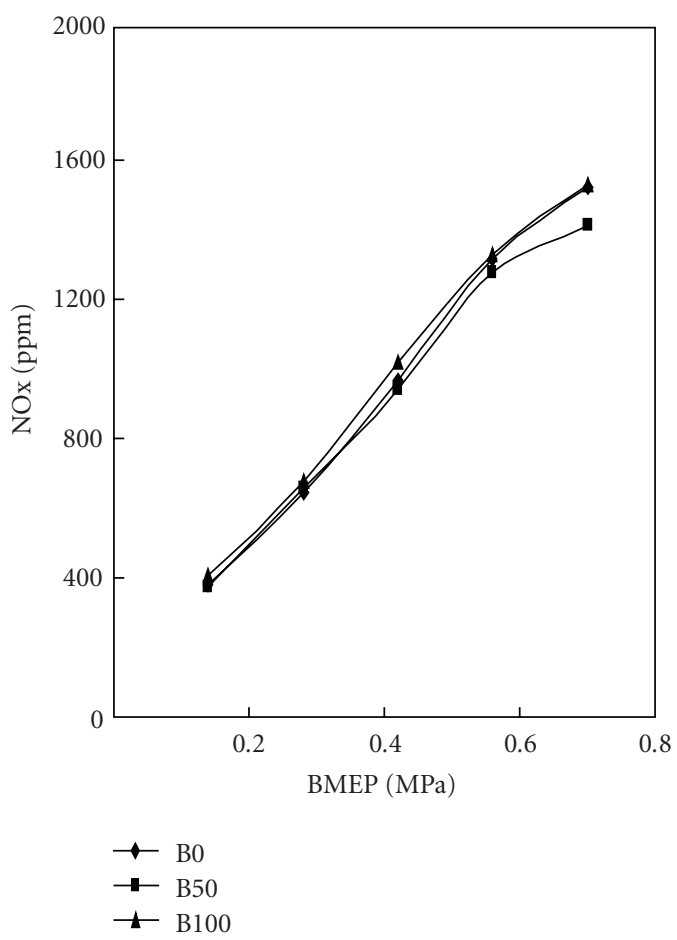

(a) $1400 \mathrm{rpm}$

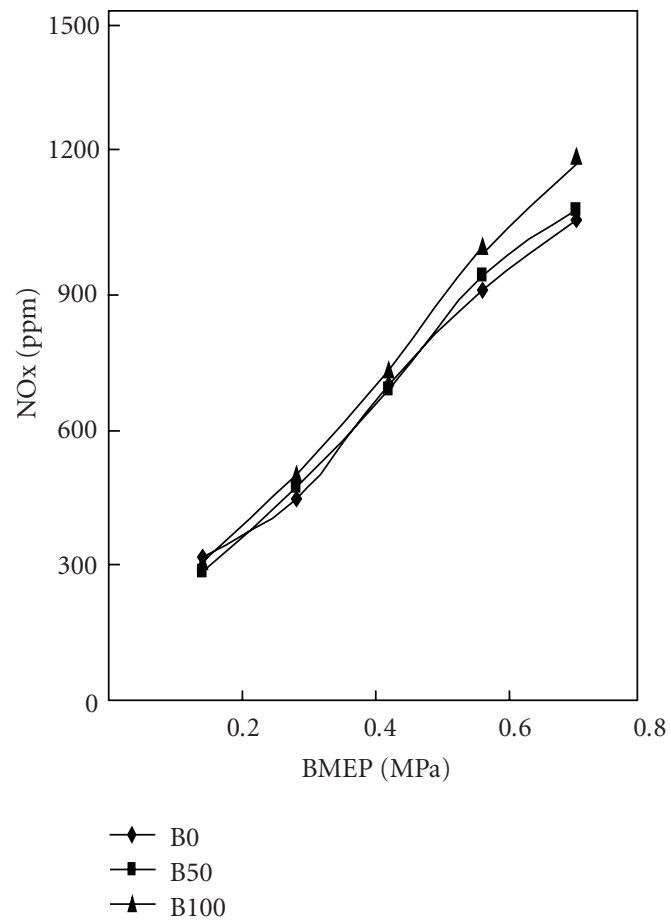

(b) $2000 \mathrm{rpm}$

FIGURE 7: Effect of the rapeseed oil monoester on NOx emissions.

TABLE 5: $\mathrm{P}^{1 P} \mathrm{H}$ NMR data of rapeseed oil monoester.

\begin{tabular}{lccc}
\hline $\begin{array}{l}\text { Chemical } \\
\text { shift/ppm }\end{array}$ & $\begin{array}{c}\text { Proton peak } \\
\text { splitting }\end{array}$ & $\begin{array}{c}\text { Coupling } \\
\text { constant/Hz }\end{array}$ & $\begin{array}{c}\text { Peak } \\
\text { area/proton } \\
\text { number }\end{array}$ \\
\hline 5.359 & quartet & 6.4 & $1.001 /-$ \\
4.228 & triplet & 3.6 & $0.78 / 2$ \\
3.596 & triplet & 3.6 & $0.83 / 2$ \\
3.395 & singlet & - & $0.99 / 3$ \\
$<2.771$ & more & - & more \\
\hline
\end{tabular}

with B0. Similar to the changing patterns at $2000 \mathrm{rpm}, \mathrm{CO}$ emissions were lowered by $16.0 \%-50.0 \%$ when the engine combusted B100; a slightly larger decline also emerged for B50 with diesel fuel. Because of the low calorific value of biodiesel at the high load and the low temperature in cylinder, combustion is not sufficient. Another explanation for the increasing $\mathrm{CO}$ emissions may be that oil-rich areas may be formed when the combustion begins to deteriorate, causing the $\mathrm{CO}$ emissions to increase gradually.

Figure 7 exhibits the results of NOx under different BMEP at 1400 and $2000 \mathrm{rpm}$, respectively. Clearly, NOx emissions did not change noticeably in general. This is due to more adequate oxygen of the mixture at the small load for diesel engines, and the lower temperature in the combustion chamber causing lesser $\mathrm{NOx}$ emissions and lower gas temperature. Biodiesel has high cetane number and short ignition delay; however, there is a trend to reduce NOx emissions. With increased combustion, the maximum temperature also increases in the combustion chamber, which is a major factor facilitating an increase in the production and emission of NOx. As a result, the NOx of biodiesel is slightly less than that of diesel at $2200 \mathrm{rpm}$.

The effect of the rapeseed oil monoester on unburned $\mathrm{HC}$ emissions at 1400 and $2000 \mathrm{rpm}$ were also investigated in the experiment. $\mathrm{HC}$ emissions at levels from $8-13 \mathrm{ppm}$ when the engine was fueled with the diesel fuel dropped to $1-3 \mathrm{ppm}$ when fueled with the blend. However, when the engine burned B100, unburned HC increased to the same levels equal to that of the pure diesel fuel. The change fluctuated with BMEP increase. This may be attributed to the lower heating value of biodiesel when mixed with diesel fuel. The ignition delay was decreased, resulting in the reduction of heat in the combustion process. Thus, the temperature of gas starts to drop increasingly, causing the quenching layer to thicken in chamber. Because the fuel of quenching layer does not vaporize, a greater amount of unburned HC does not participate in the combustion as the quenching layer thickens. When the amount of unburned $\mathrm{HC}$ becomes more than the amount of decreased part of $\mathrm{HC}$ due to the extra oxygen from oxygenated fuels, $\mathrm{HC}$ emissions increase.

3.3. Combustion Performances. Figure 8 displays the test results of in-cylinder pressure when the tested diesel engine burnt three fuels at 1400 and $2000 \mathrm{rpm}$. Under BMEP of $0.14 \mathrm{MPa}$ and speed of $1400 \mathrm{rpm}$ engine in-cylinder pressure was noticeably enhanced. This occurred when the engine was fueled with B100 in place of the reference diesel fuel. The in-cylinder peak pressure was raised by approximately $2.0 \%$ 


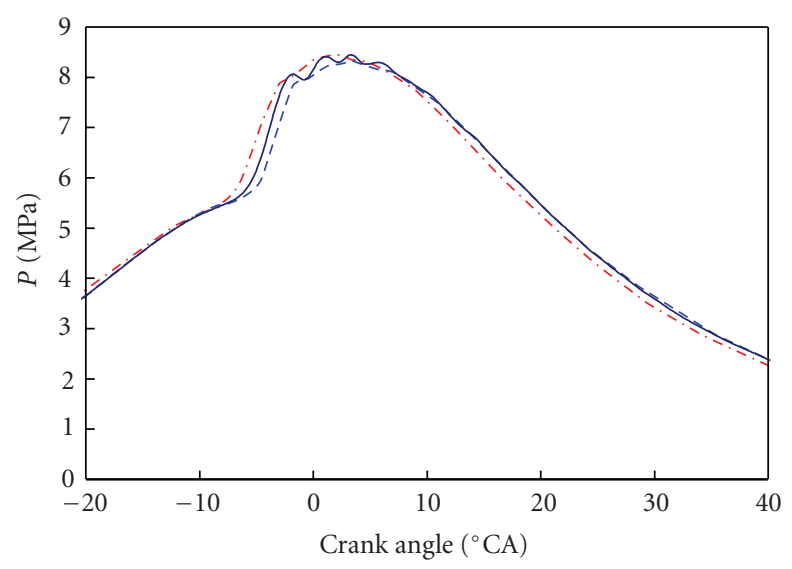

(a) $\mathrm{BMEP}=0.14 \mathrm{MPa}(1400 \mathrm{rpm})$

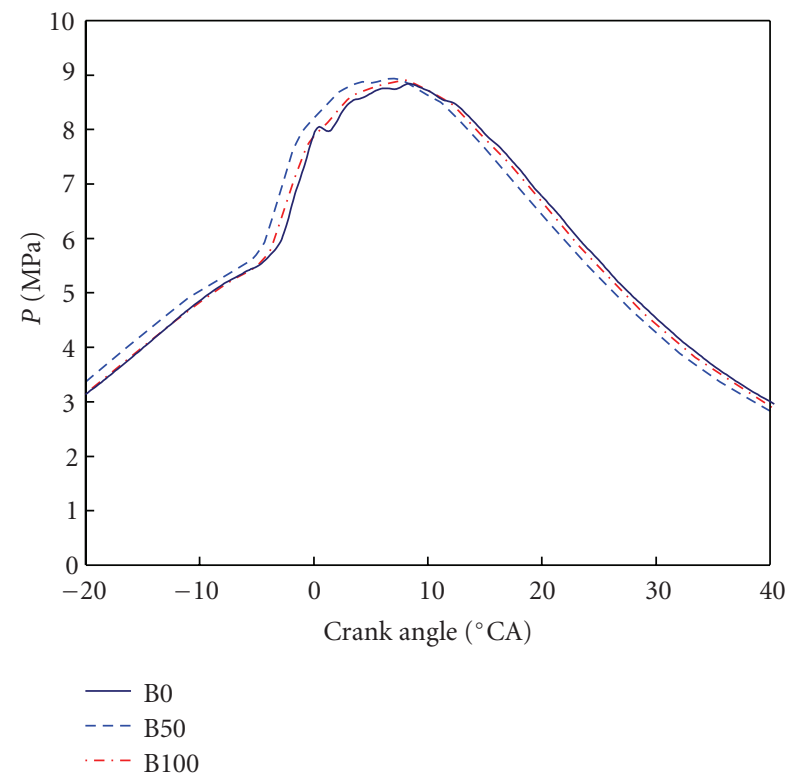

(b) $\mathrm{BMEP}=0.70 \mathrm{MPa}(2000 \mathrm{rpm})$

FIGURE 8: Diesel engine in-cylinder pressure when burning different fuels.

when burning B100. The peak pressure was also observed to rise when combusting B50. The engine ignition delay clearly became shorter when the biodiesel was substituted with B0. The new biodiesel spontaneously ignited at approximately $1.1^{\circ} \mathrm{CA}$ earlier than B0. Under BMEP of $0.70 \mathrm{MPa}$ and speed of $2000 \mathrm{rpm}$, these remarkable changes also occured obviously, as shown distinctly in the figure. The engine ignition delay was $1.5^{\circ} \mathrm{CA}$ shorter than that of diesel fuel. In-cylinder peak pressure also increased by approximately $6.9 \%$ when fueled with the new biodiesel. This is because B100 with the high oxygen content has a greater amount of premixed combustion than $\mathrm{B} 0$, which means its heat released is so concentrated that the maximum cylinder pressure rises.

Figure 9 exhibits the change rates of engine in-cylinder pressure with the crank angle at 1400 and $2000 \mathrm{rpm}$, respectively. The two graphs clearly show that in-cylinder pressure change rate increased slightly under the engine running

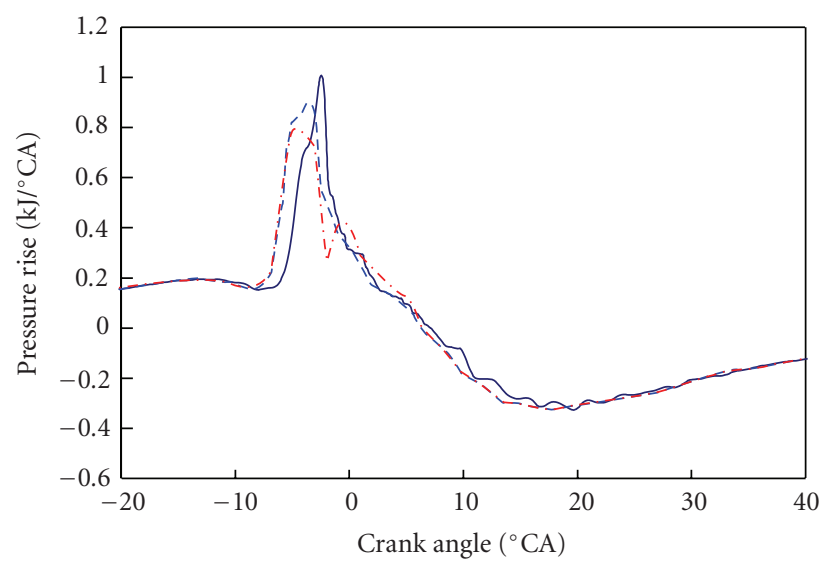

(a) $\mathrm{BMEP}=0.14 \mathrm{MPa}(1400 \mathrm{rpm})$

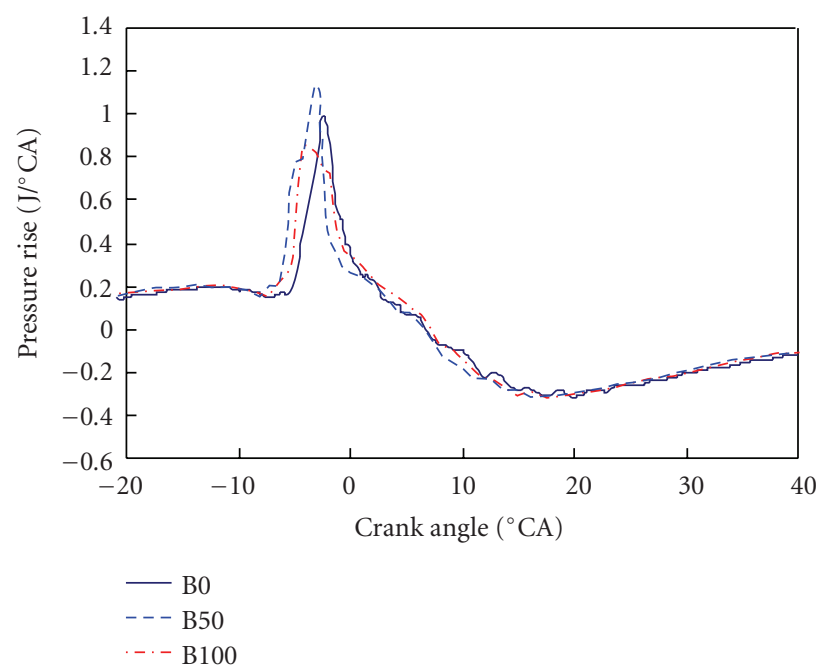

(b) $\mathrm{BMEP}=0.70 \mathrm{MPa}(2000 \mathrm{rpm})$

FIGURE 9: Diesel engine in-cylinder pressure changing rate when burning different fuels.

modes (a) and (b), when the diesel engine combusted B100. This means that the combustion rate of the new biodiesel in diesel engine increased and its combustion duration was shorter than that of diesel fuel. The two figures also distinctly reveal that the new biodiesel began to burn earlier than the diesel fuel.

Figure 10 demonstrates the heat release rates of the diesel engine when it was fueled with the biodiesel, diesel fuel, and a mixture of both. Under two modes, the heat release rate increased when the biodiesel replaced the reference diesel fuel during the experiment. At the mode (a), no change was observed in the heat release rate. This indicates that the combustion velocity of the new rapeseed oil monoester in diesel engine combustion chamber was much higher than diesel fuel, likely because the oxygen contained in the new biodiesel is able to accelerate the engine combustion. The curves in the two figures also clearly show that the new biodiesel began to burn earlier than diesel fuel. This implies that the cetane number of the new biodiesel is higher than that of diesel fuel with CN45 to CN 50 


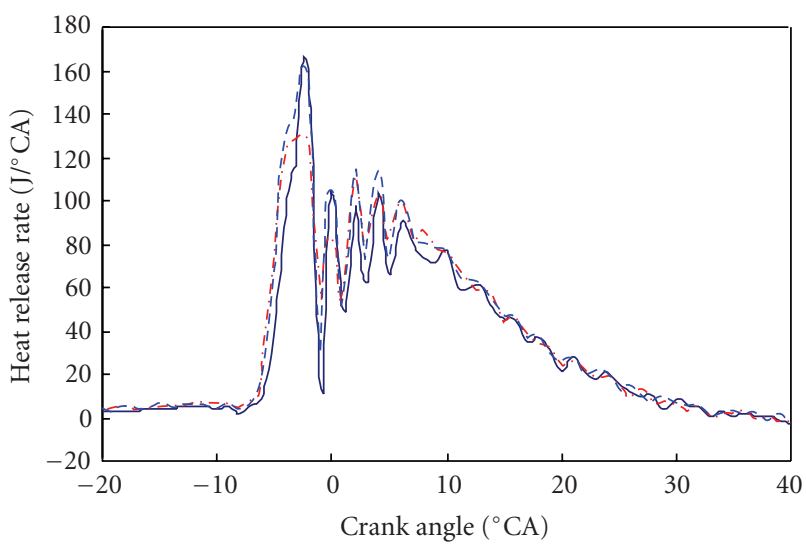

(a) $\mathrm{BMEP}=0.14 \mathrm{MPa}(1400 \mathrm{rpm})$

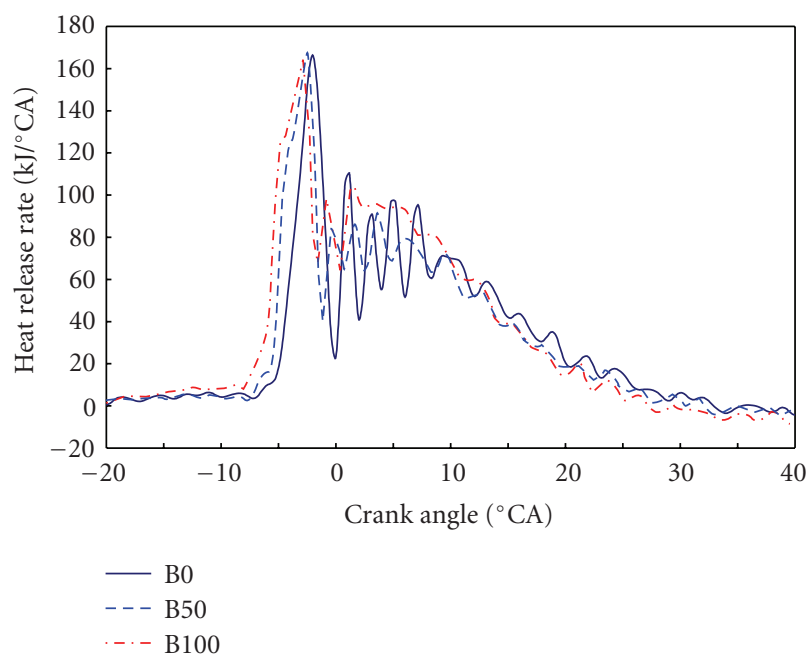

(b) $\mathrm{BMEP}=0.70 \mathrm{MPa}(2000 \mathrm{rpm})$

Figure 10: Diesel engine heat release rate when burning different fuels.

currently used in China. This higher cetane number is likely because the introduced ether group in the biodiesel is more easily oxidized. The biodiesel also releases more heat at a given time, raising the temperature, thereby accelerates fuel oxidation. The cetane number of the new biodiesel is being further determined in the laboratory.

Figure 11 demonstrates the improved engine thermal efficiency when biodiesel and the biodiesel-diesel blend replaced the reference diesel fuel in the experiment. A significant increase of $13.5 \%-20.4 \%$ in engine thermal efficiency was observed when the tested engine burnt the new biodiesel in place of diesel fuel at $1400 \mathrm{rpm}$. A similar result was attained at $2000 \mathrm{rpm}$. This may be explained by the fact that the new biodiesel contains a certain amount of oxygen, which promotes a more complete combustion of the biodiesel than diesel fuel.

\section{Conclusions}

(1) A novel biodiesel named rapeseed oil monoester of ethylene glycol monomethyl ether, which contains

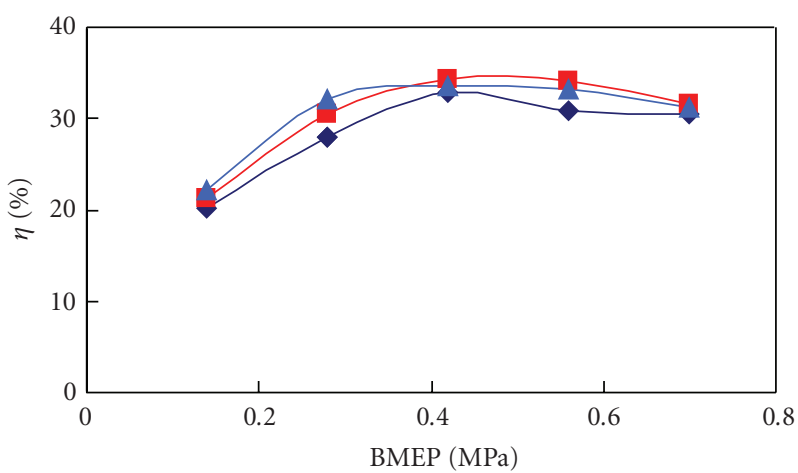

(a) $1400 \mathrm{rpm}$

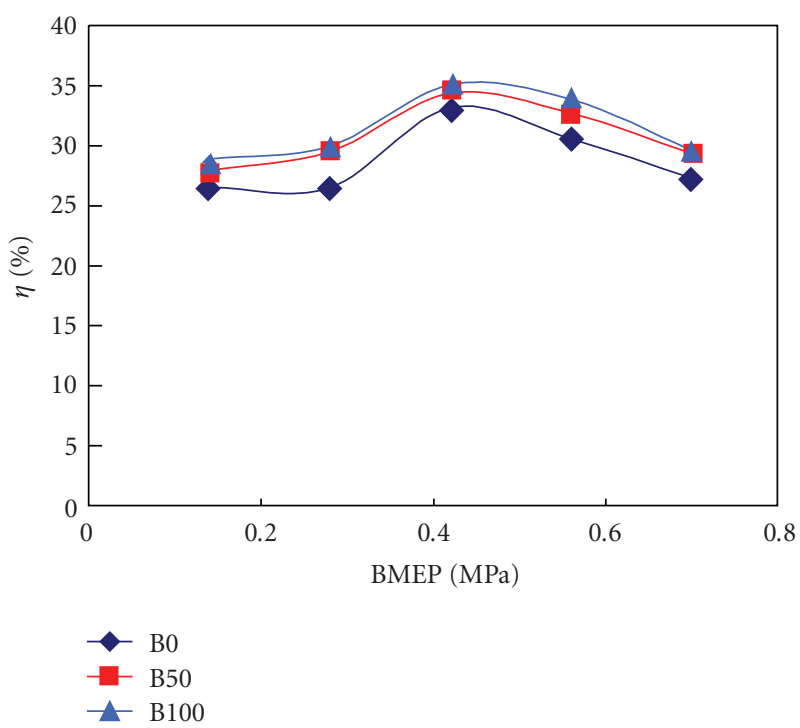

(b) $2000 \mathrm{rpm}$

FIGURE 11: Engine brake thermal efficiency when burning different fuels.

more oxygen than traditional rapeseed oil alkyl ester, has been prepared and structurally identified.

(2) When diesel engine is fueled with this rapeseed oil monoester and its mixture with diesel fuel in the proportion of $1: 1$ by volume, engine-out exhaust emissions such as smoke and $\mathrm{CO}$ can be substantially reduced under partial load modes. However, NOx emissions do not change significantly in general.

(3) When diesel engine is fueled with the new biodiesel in place of diesel fuel, both engine in-cylinder pressure and its changing rate with crankshaft angle increase to some extent. Biodiesel has a much higher cetane number and shorter ignition delay than diesel fuel, and therefore ignites earlier during diesel engine operation.

(4) The combustion of the new rapeseed oil monoester can lead to a slightly higher heat release rate than diesel fuel. Utilization of the new biodiesel can remarkably improve engine brake thermal efficiency because of its specific oxygen content. 


\section{Acknowledgment}

This research was supported by the National Natural Science Foundation of China (Grant no. 50976125).

\section{References}

[1] R. Crooles, "New findings on combustion behavior of oxygenated synthetic diesel fuels," Biomass and Bioenergy, vol. 30, pp. 461-468, 2006.

[2] M. Pugazhvadivu and K. Jeyachandran, "Experimental studies of the impact of CETANERTM on diesel combustion and emission," Renewable Energy, vol. 30, pp. 2189-2202, 2005.

[3] G. Kaplan, R. Arslan, and A. Surmen, "Modeling the effects of oxygenated fuels and split injections on DI diesel engine performance and emission," Energy Sources, vol. A28, pp. 751$755,2006$.

[4] N. Usta, E. Ozturk, O. Can, and E. Conkur, "Emission characteristics of a navistar $7.3 \mathrm{~L}$ turbo diesel fueled with blends of oxygenates and diesel," Energy Conversion and Management, vol. 46, pp. 741-755, 2005.

[5] M. Lapuerta, O. Armas, and R. Ballesteros, "Oxygenated fuels for particulate emissions reduction in heavy duty DI diesel engines with common rail fuel injection," Fernandez Fuel, vol. 84, pp. 773-780, 2005.

[6] M. Cetinkaya and F. Karaosmanoglu, "The effect of oxygenated fuels on emissions from a modern heavy-duty diesel engine," Energy \& Fuels, vol. 19, pp. 645-652, 2007.

[7] D. Y. C. Leung, X. Wu, and M. K. H. Leung, "A review on biodiesel production using catalyzed transesterification," Applied Energy, vol. 87, no. 4, pp. 1083-1095, 2010.

[8] J. Feng, Structure Analysis and Identification of Organic Compound, Defense Industry, Beijing, China, 2003.

[9] G. Fontaras, G. Karavalakis, M. Kousoulidou et al., "Effects of low concentration biodiesel blends application on modern passenger cars. Part 2: impact on carbonyl compound emissions," Environmental Pollution, vol. 158, pp. 2496-2504, 2010.

[10] X. Wang, Z. Huang, O. A. Kuti, W. Zhang, and K. Nishida, "Experimental and analytical study on biodiesel and diesel spray characteristics under ultra-high injection pressure," International Journal of Heat and Fluid Flow, vol. 31, no. 4, pp. 659-666, 2010.

[11] I. M. Atadashi, M. K. Aroua, and A. A. Aziz, "High quality biodiesel and its diesel engine application: a review," Renewable and Sustainable Energy Reviews, vol. 14, pp. 1999-2009, 2010.

[12] K. T. Tan, M. M. Gui, K. T. Lee, and A. R. Mohamed, "An optimized study of methanol and ethanol in supercritical alcohol technology for biodiesel production," Journal of Supercritical Fluids, vol. 53, no. 1-3, pp. 82-87, 2010. 

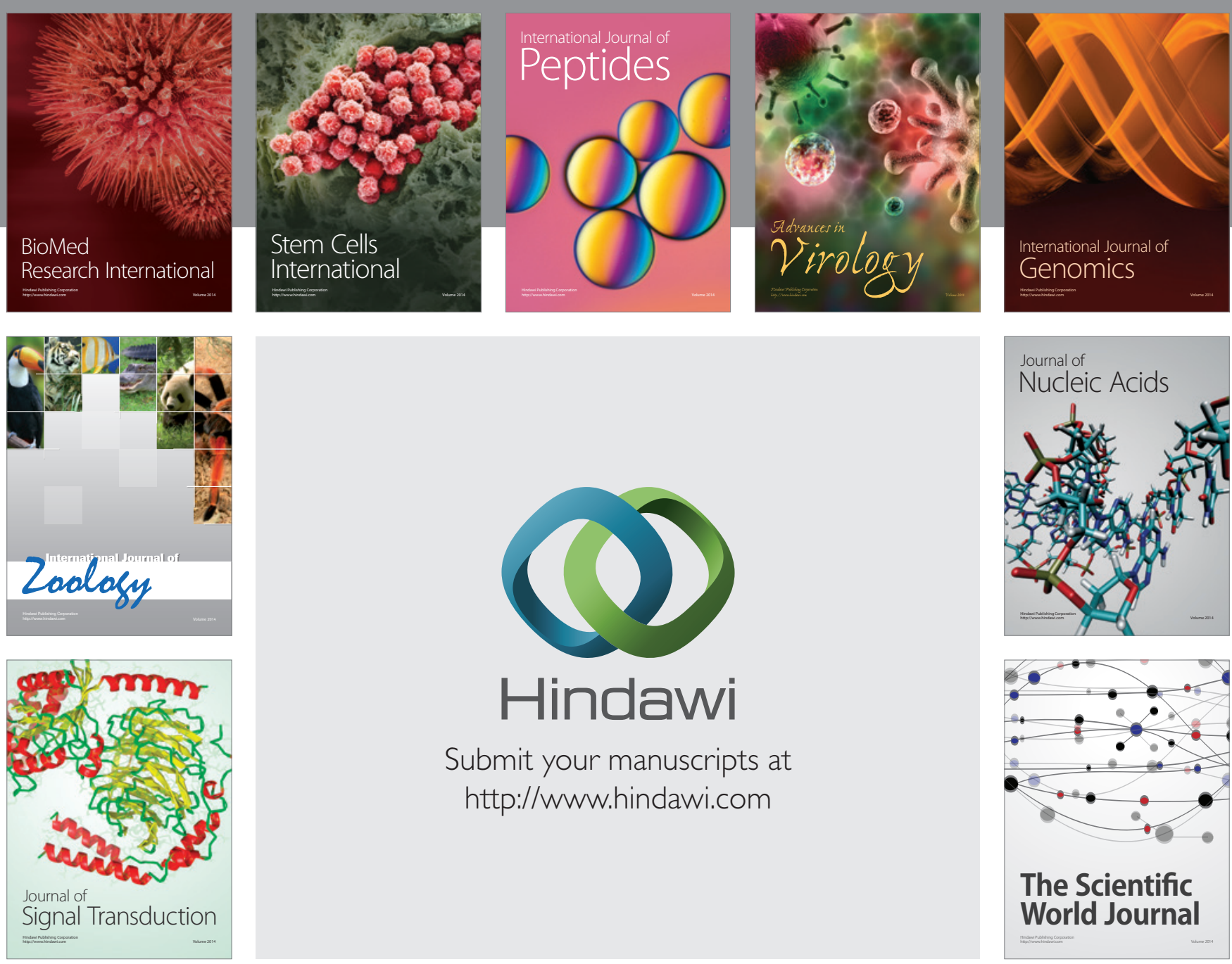

Submit your manuscripts at

http://www.hindawi.com
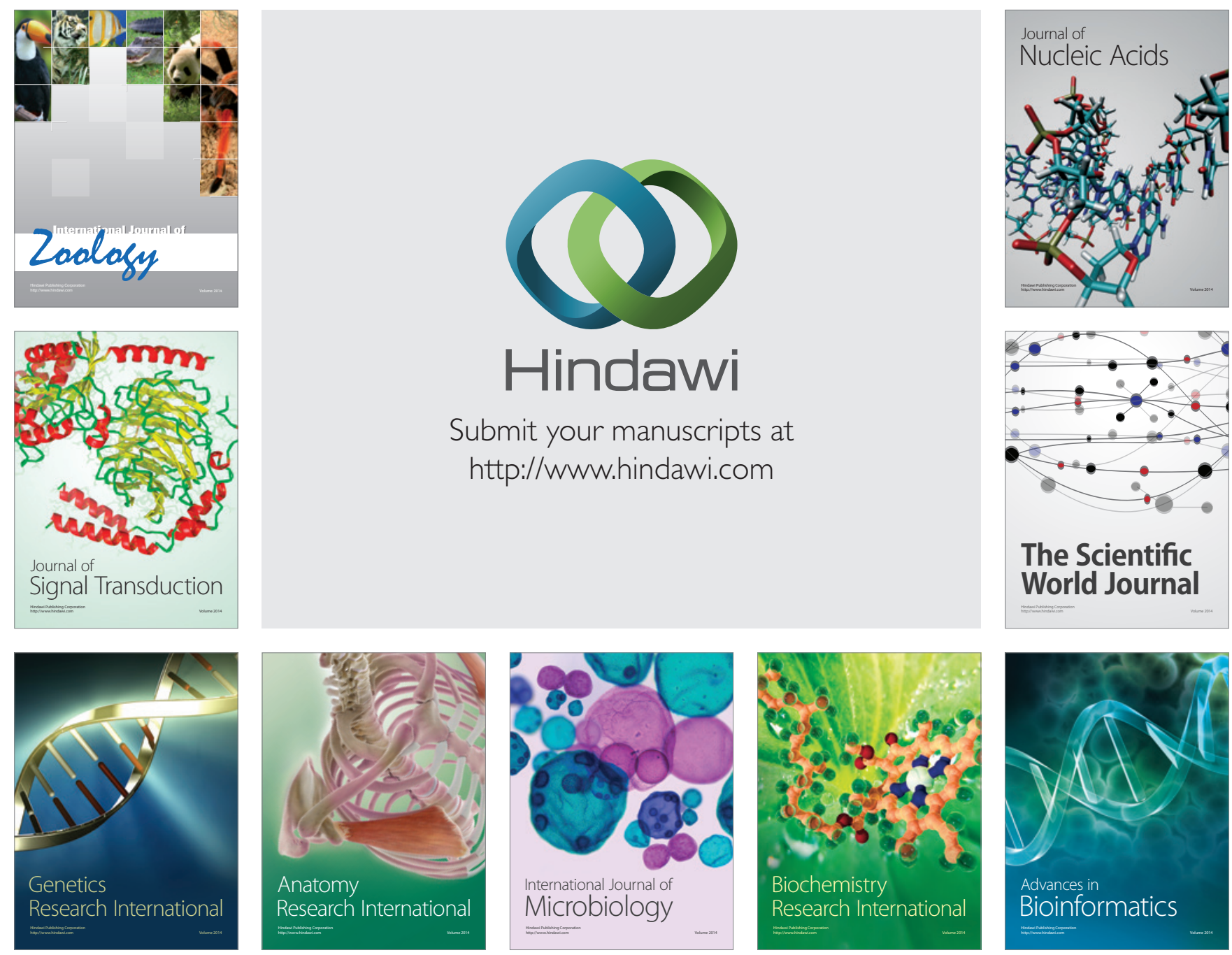

The Scientific World Journal
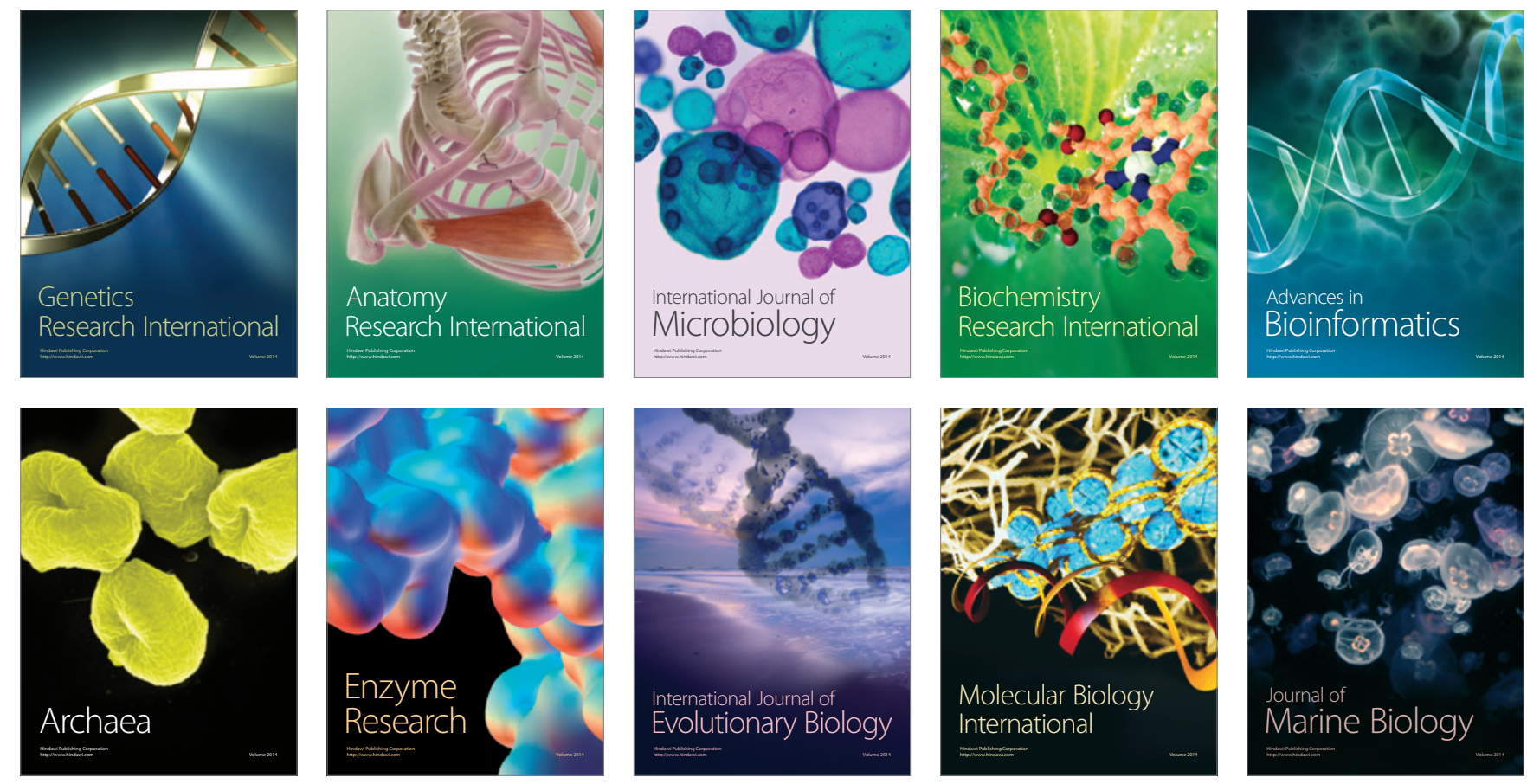